\title{
HISTORY OF GEOLOGY UP TO 1780
}

O Puche-Riart, Polytechnic University of Madrid, Madrid, Spain

(c) 2005, Elsevier Ltd. All Rights Reserved.

\section{Introduction}

Ancient civilisations in contact with nature inquired about their origins and about particular geodynamic phenomena. In most cases they satisfied themselves with empiric explanations; they even used deities in order to understand inexplicable situations.

Little by little humans learnt how to observe their environment and arrange processes. During the Renaissance the first geologic principles were born and this knowledge spread rapidly. Natural phenomena were understood in terms of dynamic cause-effect, although many dogmatic and magic interpretations persisted.

Many authors agree that geology, began to be structured as a science in the second half of the eighteenth century with Abraham Gottlob Werner (17491817), father of Neptunism (Figure 1). However, some geologic paradigms such as diluvialism existed before neptunism; all of them contained countless mistakes and ambiguities.

This article outlines the period up until 1780, which thus incorporates the work of James Hutton (see Famous Geologists: Hutton). His ideas were important in the development of geology, more specifically relating to the origins and dating of rocks. Geology was not completely defined till the birth of Stratigraphy at the end of the eighteenth century and Palaeontology at around 1830.

\section{The Dawn of Geology}

Thinking about the Earth first occurred when man, faced with natural phenomena such as earthquakes and volcanoes, posed questions about such phenomena and sought to provide answers in naturalistic terms. Practical matters, such as the task of prospecting for mineral resources, also stimulated interest in the Earth.

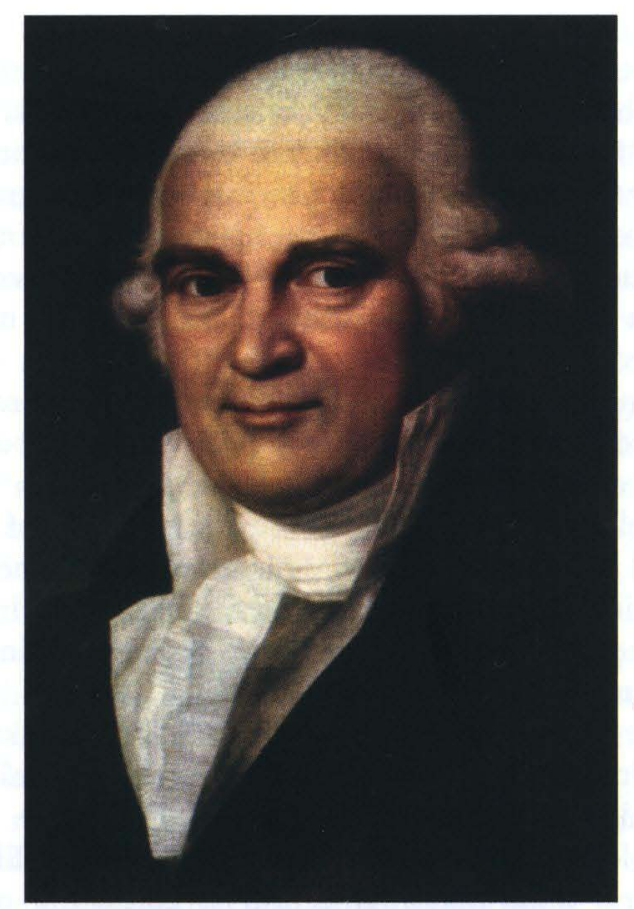

Figure 1 Abraham Gottlob Werner (1749-1817). Father of Neptunism. 
The Greek philosophers thought that the universe was governed by unchanging principles and with intelligible and discoverable natural laws. This contrasted with the mythopoeic or magical explanations of nature found more generally in the ancient world and in non-scientific cultures today.

In his Histories, Herodotus of Halicarnassus (Ca 484-425 BC) spoke of the sedimentary loads of the Nile and of the slow growth of its delta. This was perhaps the first recorded statement based on observation indicating an awareness of the magnitude of geological time. But myth and naturalistic explanation were intertwined in Greek thought.

Plato (427 or 428-348 BC) (in Phaedo, 111-112) described the Earth as having internal passages carrying "a vast tide of water, and huge subterranean streams of perennial rivers, and springs hot and cold, and a great fire, and great rivers of fire, and streams of liquid mud, thick or thin", as well as a great internal chasm, Tartarus. Water moved with a 'see-saw' motion within the Earth, like the tides, and produced springs that fed rivers and streams, and returned to the sea and thence to Tartarus. The surging waters also generated great winds inside the Earth. Volcanoes were produced by the escape of rivers of fire from within. These speculations were naturalistic, but also explicitly said by Socrates to be 'myth'. Such ideas were to endure until the eighteenth century.

Along similar lines Aristotle (384-322 BC), a pupil of Plato, suggested that earthquakes were caused by subterranean winds passing through cavities within the Earth. Fossils were nature's failed attempts in the creation of living beings (the theory of vis plastica).

Although some authors consider Theophrastus of Ephesus ( $\mathrm{ca} 371-\mathrm{ca} 287 \mathrm{BC}$ ) to have written the first mineralogical treatise, Perilithon, there are references to a work, now lost, written by his teacher Aristotle. In the surviving Meteorologica, Aristotle ascribed the origin of minerals and metals to dry/smoky or moist/ vaporous exhalations from within the Earth.

Minerals' curative purposes were considered in Dioscorides' De materia medica (ca 77 AD). Processes such as saline crystallization or exfoliation were remarked upon, and origins of substances of supposed medicinal value were mentioned. This medical tradition was to continue in the attempted mineral/ chemical cures advocated by Paracelsus in the sixteenth century.

The Romans were less interested in abstract knowledge than were the Hellenes, but were practical, and skilled in the use of stone for building. The most notable Latin 'scientific' text was Pliny the Elder's Historia naturalis (first century), consisting of 37 books, uncritically compiled from 2000 works of antiquity. The last five books dealt with the mineral kingdom, with mining and smelting practices, and with the characters, occurrences, and uses of many mineral substances.

On observing sea shells in the mountains, Ovid (43 $\mathrm{BC}-17$ or $18 \mathrm{AD}$ ) inferred that those lands had formerly been covered by the sea. He also realised how fluvial valleys could be formed and how water gradually reduced relief. The materials swept along would be deposited, lower down, in flooded areas, where on drying and hardening they would become rocks. We have for the first time the pattern: erosion, transportation, sedimentation, and lithification.

The idea of the regeneration of minerals and ores in mines was advanced by Pliny's teacher, Papirio Fabiano, an idea still maintained in the seventeenth century, as in the case of Alvaro Alonso Barba in $E l$ arte de los metales (1637). In this work, the Earth supposedly had the ability to 'reproduce', as envisaged in antiquity.

During the Dark and Middle Ages, Aristotle's influence continued in the West, but linked with Christian viewpoints. Thus, for example, St Isidore of Seville's (560-636), in Etymologies (a work considered to be the first encyclopedia), pointed to the organic origin of fossils, but connected them with the Flood.

Alchemy coming from Persia (eighth-nineth centuries) influenced the works of Ibn Sina (Avicenna) (930-1037) and subsequently Christian authors like Alfonso X (1221-1284), Raymond Lully (12351315), Arnaldo Vilanova (ca 1238-1311), Ulisse Aldrovandi (1527-1605), Andreas Libavius (15601616), and Alonso Barba (1569-1662). There developed the so-called theory of the opposites whereby things combined or repelled one another according to their 'sympathies' or 'antipathies'. Some spoke of the gender of minerals. For example, the word 'arsenic' derives from the Greek word for male. Minerals supposedly formed from the appropiate combinations. Alchemy was the forerunner of inorganic chemistry.

Another feature of the Middle Ages was the proliferation of 'lapidaries': list of stones, etc., with descriptions of their properties, uses, etc. Ibn Sina wrote De lapidibus, in which minerals were classified according to the quadrichotomy: stones/earths; metals ('fusibles'); sulphurous fossils (combustibles); salts ('solubles'). Ahmad Al Biruni (973-after 1050) mentioned more than 100 minerals and metals in his treatise on gems (Kitab-al-Jamahir), and accurately determined specific gravities for several types. Also Alfonso X of Castile (1221-1284) (Alfonso the Wise), translated numerous Arab lapidaries, where the properties of minerals supposedly varied according to the positions of the heavenly bodies. Al Biruni, born in Uzbekistan and a great traveller, was also notable for his studies of rivers. He recorded evidence for 
changes in the course of the Amu Darya River, and the decrease of sediment size down the Ganges. So (anachronistically) he could be called a fluvial geomorphologist.

The greatest Mediaeval author on the mineral kingdom was Albertus Magnus (St Albert of Cologne), Bishop of Ratisbon and doctor of the Church (1193-1280). Anticipating Renaissance authors, he stated that experience alone was the source of knowledge of physical things. He tried to link faith and reason when he pointed out that the sea could never have covered the whole Earth by natural causes. In De mineralibus he recognised about 100 mineral species. Both minerals and rocks were thought to have formed from molten masses.

\section{The First Geological Principles: The Observation Phase}

With the Renaissance, the geocentric Aristotelian and Thomist universe collapsed in the 'Copernican Revolution', and observation rather than 'authority' became central to science. For example, Bernard Palissy (1510-1590), pointed out "I have never had any other books than the skies and the Earth whose pages are open to all". Systematic ordering of the observations facilitated the establishment of the first geological principles. Information also spread faster thanks to the printing press. This was particularly true of great natural catastrophes, such as the eruption of Vesuvius in 1538, which prompted interest in the Earth.

Leonardo da Vinci (1452-1519) visited the Alps and realised that the geological structure was the same on both sides of the fluvial valleys. The rivers carried away materials to the sea, where they might bury shells. When land rose up it formed hills that, on being cut by rivers, reveal layers or strata. Shells in such strata were not carried there by the Flood. We have one of the first visions, albeit incomplete, of the geological cycle.

Palissy showed that what are today called rudist lamellibranchs are 'lost' species. This recognition of extinction was an important contribution towards recognition of the Earth's antiquity. Interest in fossils developed little by little, as when Father Jeronimo Feijoo y Montenegro (1676-1764) also cited discoveries of lost species. There was still a long way to go to before fossils were used to determine the relative chronology of the landscape.

In his Principia philosophiae (1644) the French philosopher René Descartes (1596-1650) considered the Earth as an old cooling star. There was incandescent material in its interior, around which there was a layered structure (metallic, heavy material, air-water, and outer crust). As the globe cooled, the crust cracked and collapsed, thus creating mountains and seas. In this speculative theory we have the first attempt to explain the internal structure of the eEarth in mechanical terms (i.e., in terms of the 'mechanical philosophy' according to which all natural phenomena were explained in terms of matter and motion). Descartes also saw the planet as a great 'still', heated by its internal material. So sea water penetrating into the Earth was distilled in the interior, leaving the salt there.

Descartes' theory of a central heat re-appeared in the work of the Jesuit Athanasius Kircher (16011680), Mundus subterraneus (1665), which proposed a great central pyrophylacium or repository of heat, linked also with ideas going back to Plato. The main repository was connected by channels to other lesser fires, and the network of interconnected channels served as conduits for volcanoes at various places on the surface. In addition to the pyrophylacium, there were aerophylacia, through which circulated the subterranean winds that supposedly caused earthquakes; and bydrophylacia, or water-containing caverns, which were fed from the sea and sustained springs. (The model had similarities to that in Plato's Phaedo.) Earthquakes gave rise to the formation of mountains. Kircher also revived the organicist theories, speaking about the uterus of the globe, and vis petrifica and vis seminalis (petrifying and seminal powers). The Earth was a living organism with a capacity for reproduction and the other functions of a living being (so inside the Earth salt water becomes fresh through a quasi'metabolic' process). Thereby both external and internal 'geodynamic' phenomena were explained.

Niels Stensen (1638-1686) (Nicolaus Stenonis or Steno) (see Famous Geologists: Steno), a Danish physician in the service of the Medici family in Florence, was less speculative and more original. He authored De solido intra solidum de naturaliter contento dissertationis prodromus (1669), in which, from the study of quartz crystals, the law of the constancy of interfacial angles was first recognized. With Steno, we also have what might be called the first 'stratigraphic diagram'. Sediments accumulate, forming horizontal layers in which marine or terrestrial fossils were buried, the oldest layers being below and the younger ones above. These layers could be undercut by erosion, fracturing and collapsing. Then new horizontal layers were deposited, at an angle to the earlier ones. One of geology's main problems, to establish a chronological order of events, had begun to be resolved. (Steno's principle of superposition was relatively trivial: the lowest layer of bricks in a wall is put in place before the upper ones. But it required imagination to apply this idea to the easily observed layered rocks.) 
But stratigraphy had still to be put together. Giovanni Arduino (1714-1795) made the first chronostratigraphic division (with geological plan and section included) when he divided the rocks of the Alpine landscape into: 1) Primary: formed by quartzites, and slates; 2) Secondary: formed by limestones, sandstones, and shales; 3) Tertiary: formed by limestones, sandstones, gypsums, and clays; and 4) Alluvium. The idea was set forth in two letters addressed to Antonio Vallisnieri (published 1760).

The seventeenth century was also characterized in the West by attempts to reconcile observations of natural history with the Bible, aligning 'faith and reason', in what was called 'physico-theology', or the attempted interweaving of natural philosophy (science) and religion. Such work continued well into the nineteenth century, and even to the present.

Thomas Burnet's (1636-1715) work Telluris theoria sacra (1681) provides a good example. For this Anglican cleric, the Earth's initial chaotic material was ordered by gravity, with the heaviest parts in the centre and the lightest parts at the surface. The result was a concentric structure: 1) a Kircherian or Cartesian igneous core; 2) liquid; 3 ) an oily layer; and 4) an outer crust hardened by the sun (ossatura telluris montium). When the central vapours acted on the outer crust it cracked and broke, giving rise to the Flood ("all the fountains of the great deep [were] broken up": Gen. 7, 11). If the Earth had not been flat, it could not have been covered by the waters (here reason and design were introduced). After the Flood, the waters supposedly withdrew, taking much with them, thus causing the Earth's relief. Such theories, connecting the Noachian Flood with geological observations, came to be called 'diluvialist'. An antecedent of 'classical' diluvialism was perhaps the Spaniard José González Salas (1588-1651) who, in 1650, stated that the Flood changed the face of the Earth.

For Isaac Newton's successor at Cambridge, William Whiston (1671-1752), a comet caused water escape from the Earth's interior, while for John Woodward (1665-1728), the waters supposedly dissolved the Earth, which was then converted to its present layered state as matter separated out according to the law of gravity (Essay Toward a Natural History of the Earth, 1695).

The age of the Earth was calculated in accordance with the biblical records, as Alfonso X the Wise had done in his General History. This was likewise done by the Cambridge classicist John Lightfoot (16421644); the Anglican Primate of Ireland, James Ussher (1650); and William Lloyd, Bishop of Worcester (1701). They arrived at various values between 3928 and 5199 years old. These authors, who today may seem detached from reality, were in fact careful scholars who sought to reconcile Jewish, Christiar and pagan historical records. Ussher's date for th Earth's creation ( $4004 \mathrm{BC}$ ) became the best knowr as printed in the margins in Lloyd's edition of th 'King James' Bible (1701).

Outside the religious arena, Gottfried Liebniz (1646-1716) Protogea (1684) proposed that rock had been formed by two processes: 1) the cooling $c$ fused material to give an Earth with a 'glassy' surface 2) the action of waters on this hard surface and th concretion of solid elements contained in aqueou solution. Leibniz's ideas thus anticipated the lat 18 th century debate between 'Plutonists/Vulcanist and 'Neptunists'.

José Vicente del Olmo (1611-1699), in his Ner Description of the Orb (1681), stated that the mour tains were raised up due to internal exhalations. Th elevated areas were then eroded by rain, wind, an river floods. Thus a balance was established in natur rather than a single progression of change such a Burnet envisaged. But let it be remembered that Senec (ca $3 \mathrm{BC}-65 \mathrm{AD}$ ) and the Epicureans had long befor envisaged a 'balance of nature'.

\section{Geology as a Science is Born}

The eighteenth century was characterized by the eco nomic development of the western nations and th development of democratic ideals. Inspired by th accomplishments of science and technology, the En lightenment world-view, which saw things as essen tially intelligible with problems being capable 0 solution by rational beings with minds unclouded $b$ superstition, was to be driven on by the idea of pro gress, which was born with it. New centres of teach ing such as Göttingen University were founded, an scientific publications for the technical and educate bourgeoisie, such as Denis Diderot's Encyclopédie appeared. Experimentation also acquired greate importance, even in the study of the Earth. It was period of glorification of the rational, where seemed that the only things that mattered wer those that could be counted, measured, weighed, o rationally calculated.

The end of the eighteenth century coincided wit the Industrial Revolution (England) whose founda tions were iron, coal, steam, and textile manufac tures. The need for additional natural resource boosted mining, and between 1766 and 1788 th mining academies of Freiberg, Chemnitz (now Banks Stiavnica), St Petersburg, Almaden, and Paris wer founded in that order. 'Subterranean geometry' an mineralogy were taught and mineralogy began t develop into petrography, stratigraphy, palaeon tology (later), and, eventually, geology (around th 
end of the eighteenth century). Curiously, Britain was backward in such centralized technical education.

Abraham Gottlob Werner (1750-1817) was appointed to the Mining Academy of Freiberg in Saxony in 1775 where he developed his Neptunist theory (1777), which proposed that all rocks, even basalts, were formed by chemical precipitation from a primordial ocean or allgemeines Gewaesser. (There were, however, precursors of this theory, such as the Frenchman Benôit de Maillet [1755].) According to Werner, by successive sedimentation onto an irregular terrestrial core, four types of formations were supposed to be deposited: 1) Primitive: crystalline rocks such as granite and gneiss; 2) Transitional: limestones, slates and quartzites; 3) Flöetz: formed from what we consider today to be the layered rocks from the Permian to the Cenozoic; and 4) Alluvial: (superficial) deposits. (The 'Transition' category was absent from initial exposition of Werner's theory.) These 'chronostratigraphic' divisions had previously been adumbrated in Germany by others such as Johann Lehmann (1719-1767) and Georg Christian Füchsel (1722-1773), and also by the German traveller, Peter Simon Pallas (1741-1811), in the Urals (1768). The Primitive formations would be found in the central parts of mountain ranges, from which the water would have withdrawn first.

Werner's theory gave an approximation to the order of rocks observed in the field. But there were questions that Werner's theories couldn't solve:

1. Where did the water of the supposed primordial ocean go to?

2. Is the Earth inactive? (For Werner, sloping strata corresponded to margin sedimentation.)

3. How were rocks such as basalt, found on the tops of hills, to be explained? (Werner thought that basalt was also precipitated from his ocean, the level of which supposedly rose again for some unexplained reason.)

4. How were mineral veins and dykes to be accounted for? (Werner thought that material might have precipitated from above filling rents in the crust.)

5. How were volcanoes to be explained? (Werner thought that they might be due to the combustion of subterranean coals, etc.)

6. How could the universal ocean dissolve so much siliceous matter? (This question was never answered satisfactorily, though the occurrence of siliceous springs and quartz veins in some rocks suggested precipitation from solution.)

Not everything that came from Werner was wrong. He praised observation and the use of scientific method and he assisted into the emergence of geognosy or geology, 'oryctognosy' or mineralogy. With Werner (and before him in Russia with Lomonosov [1711-1765]), mineralogy acquired its own body of doctrine. He classified minerals according to their external characteristics (physical properties), as Linnaeus (another important Enlightenment figure) had done with plants and animals, between 1735 and 1760 . The observation of crystalline forms was to lead to the birth of crystallography. This science had taken its first steps beyond Steno thanks to the Swiss naturalist Moritz Anton Capeller (16851769) with his Prodomus cristallographie (1723) and the Frenchman Jean Baptiste Louis Romé de l'Isle's (1736-1790) Essai de cristallographie (1772), soon to be developed further by René-Juste Haüy.

Werner was to have many disciples who would write important pages in the annals of geology during the nineteenth century, such as Guyton de Morveau (1737-1816), Horace Bénédict de Saussure (17401799), Déodat Gratet de Dolomieu (1750-1801), Juan José Elhuyar (1754-1896), Fausto Elhuyar (1755-1833), Andrés Manuel del Río (1765-1849), Alexander von Humboldt (1769-1859), Leopold von Buch (1774-1853), Robert Jameson (1774-1854), etc. They tried to use his stratigraphic order, worked out in Saxony, as a 'paradigm' for examining and interpreting rocks in other parts of the world.

Another notable eighteenth-century authority was the keeper of the Jardin des Plantes in Paris: Georges Louis Leclerc, Comte de Buffon (1707-1788), author of a great 36-volume Histoire naturelle. In a supplement of this work entitled Époques de la nature (1778) he put forward three basic ideas: 1) a longer duration of geological time (compared with the Biblical account); 2) organic evolution, preparing the way for transmutationism and evolutionism; and 3) palaeogeography.

Like Descartes, Buffon thought that mountains were formed by contraction during the Earth's cooling. He also examined the problem of the age of the Earth experimentally, heating spheres of different sizes and measuring how long they took to cool until they could be touched; and by analogy he estimated the possible age of the Earth. He arrived at the conclusion that it would have taken 74832 years to have cooled to its present temperature (and privately speculated on the possibility of a much greater age).

Through further experimentation Buffon obtained silicates by melting clays. Nevertheless, he held to some older ideas, such as the view that earthquakes were caused by explosions of gases in the Earth's cavities or that volcanoes were produced by the combustion of sulphur and bitumen.

The hydrological cycle was also quantified, in accordance with the calculations of Edmé Marriotte 
(1690), Pierre Perrault (1674), and the suggestion of Edmund Halley (1714-1716) that one could measure the rate of increase of salinity in lakes that had no discharge rivers, and then gauge how long it might have taken for the oceans to acquire their salinity. Nevertheless, eighteenth-century geology was not obviously an experimental science. It was not then possible to reproduce variables such as pressure, temperature, or time, which reach very high values in many of the processes occurring in nature.

In the eighteenth century there were still authors who regarded fossils as 'figured stones', as did the French physician Pierre Barrère, author of Observations sur l'origine et la formation des pierres figurées (1746). The diluvialist school was also active. Thus, for the Spaniard, Father Antonio Torrubia, in his Aparato para la historia natural (1754), fossils were represented as remains of the Flood. Nevertheless, a significant rejection of diluvialism occurred in the mid-eighteenth century, mainly in central Europe, with authors, such as the Göttingen professor Samuel Christian Hollmann (1753), while the Swiss cleric Johan Georg Sulzer (1762), pointed out the marine origin of fossils. Numerous examples were described and the natural history cabinets were filled with specimens, but without an agreed system for their cataloguing. Although the influential Werner rejected fossils as the basis for the study of stratification, they began to gain in importance, and increased knowledge began to pave the way for the birth of stratigraphy, at the end of the century, and of scientific palaeontology, which entered at the end of the eighteenth century.

Practical matters were also important in the Enlightenment. Between 1778 and 1782, Jean Étienne Guettard (1715-1786) and Inspector General of Mines Antoine Grimoald Monet (1734-1817) jointly published their Atlas minéralogique de la France, which showed the distribution of deposits of economic significance across their country. In Sweden, the chemist Torbern Bergman (1777) initiated general methods of mineral analysis in the 'humid' way, bringing mineral substances into solution by the action of acids or alkalis and then identifying components by a sequence of precipitation reactions. Prospecting for coal was enhanced by boring techniques, but without palaeontological control the results were not always useful through misidentification of strata.

The great catastrophe of the Lisbon earthquake on 1 November, 1775 , sowed pessimism in the scientific world. There were many, including Buffon, who thought of the progressive degradation of the cooling globe. But in Spain, the naturalist Brother Benito Feijoo y Montenegro, in his Cartas eruditas y curiosas
(1760), tried to calm things down by pointing out th greater the force of the previous one and that repeti tions of earthquakes are less likely. In Germany, Im manuel Kant argued that earthquakes had natura causes and had nothing to do with the moral condi tion of mankind. But they could remind us not to tr to find happiness in worldly goods. Old earthquak myths endured nevertheless, and it was only at th end of the nineteenth century that geologists began t suspect the main causes of tremors.

\section{See Also}

Biblical Geology. Famous Geologists: Hutton; Steno Geomythology. History of Geology From $1780 \mathrm{TC}$ 1835. Minerals: Definition and Classification. Strati graphical Principles.

\section{Further Reading}

Ellenberger F (1988) Histoire de la Geologie Tome 1 De Anciens à la première moitié du XVIIe siècle. Paris Technique et Documentation - Lavoisier.

Ellenberger F (1994) Histoire de la Geologie Tome 2 L grande éclosion et ses prémices 1660-1810. Paris London, and New York: Technique et Documentation. Lavoisier.

Faul $\mathrm{H}$ and Faul C (1983) It Began with a Stone: A Histor. of Geology from the Stone Age to Age of Plate Tectonics New York, Chichester, Brisbane, Toronto and Singapore John Wiley \& Sons.

Gaudant G and Bouillet G (2000) La genèse et l'interpréta tion des 'fossiles' dans la science classique: de la Renais sance aux Lumières. Bulletin de la Société Géologiqued France 171: 587-601.

López Azcona JM (1985) Los jheólogos. Revista d Materiales y Procesos Geológicos 3: 179-187.

Mather KF and Mason SL (1939) A Source Book $i_{i}$ Geology. New York and London: McGraw-Hill.

Oldroyd DR (1996) Thinking about the Earth: A History c Ideas in Geology. Cambridge (Mass): Harvard Universit Press.

Pelayo F (1996) Del Diluvio al megaterio. Los orígenes d la paleontología en España. Madrid: Consejo Superior d Investigaciones Ciéntificas.

Rappaport R (1997) When Geologists were Historian! 1665-1750. Ithaca and London: Cornell Universit Press.

Rossi P (1984) The Dark Abyss of Time: The History of th Earth of the History of Nations from Hooke to Vicc Chicago and London: The University of Chicago Press.

Sequeiros L (2003) Las raíces de la Geologia: Nicolas Stenc los estratos y el diluvio universal. Enseñanza de la Ciencias de la Tierra (10,3): 217-242.

Wagenbreth O (1999) Geschichte der Geologie in Deutsck land. Stuttgart: Georg Thieme Verlag.

Wendell E Wilson (1994) The history of mineral collecting Mineralogical record 25(6): 1530-1799. 